\title{
Strategi Perencanaan dan Biaya Pemasaran yang Efektif bagi UMKM Mitra Binaan PT. Semen Indonesia
}

\author{
Erwin Saraswati \\ Universitas Brawijaya \\ erwin_saraswati@yahoo.com
}

Submitted: $31^{\text {st }}$ July 2019. Revised: $11^{\text {th }}$ October 2019. Accepted: $31^{\text {st }}$ October 2019

Key word:

$M S M E$, marketing strategy, marketing planning, marketing expenses

\section{Kata Kunci}

UMKM, strategi pemasaran, perencanaan pemasaran, biaya pemasaran

\section{Abstract}

Micro, Small, and Medium Enterprises (MSMEs) in Indonesia play an important role in the economy, as they contribute to $57-60 \%$ of national GDP and employ $97 \%$ of all labors in the country. Besides raising capital, the main problem of MSMEs are marketing their products. Most MSME businessmen are merely product-oriented, not consumer-oriented and tend to focus only on fulfilling their families' needs. So do the Fostered Partners of PT Semen Indonesia. After we conduct a training session, an FGD grouped by types of business, and knowledge sharing on web-based technology, MSMEs should be able to solve marketing-related problems and always budget marketing expenses.

\section{Abstrak}

Bisnis Usaha Mikro, Kecil dan Menengah (UMKM) di Indonesia berperan penting dalam perekonomian, dikarenakan UMKM telah memberikan kontribusi pada Produk Domestik Bruto (PDB) sebesar 57$60 \%$ dan menyerap tenaga kerja sebanyak $97 \%$ dari seluruh tenaga kerja nasional. Selain permodalan, permasalahan utama UMKM adalah pemasaran produk-produk yang mereka hasilkan. Para pelaku bisnis UMKM seringkali hanya berorientasi pada produk dan bukan konsumen, serta cenderung berfokus pada pemenuhan kebutuhan keluarga mereka saja. Demikian pula UMKM yang menjadi mitra binaan PT Semen Indonesia. Setelah dilakukan pelatihan, pembentukan kelompok diskusi (FGD) berdasarkan jenis usaha, serta pemberian pengetahuan mengenai teknologi berbasis web, UMKM diharapkan dapat memecahkan permasalahan pemasaran dan selalu menganggarkan biaya pemasaran. 


\section{PENDAHULUAN}

Jumlah UMKM (Usaha Mikro

Kecil Menengah) di Indonesia terus meningkat, seiring dengan pertumbuhan usia produktif. Berdasarkan data Kementrian Koperasi dan Usaha Kecil Menengah, jumlah UMKM sampai tahun 2014 terdapat sekitar 57,8 juta dan diperkirakan akan terus bertambah. Bisnis UMKM ini menjadi penting, dikarenakan UMKM telah memberikan kontribusi pada Produk Domestik Bruto (PDB) sebesar 57$60 \%$ dan tingkat penyerapan tenaga kerja sekitar 97\% dari seluruh tenaga kerja nasional (Profil Bisnis UMKM-LPPI dan BI, 2015). Dalam lima tahun terakhir, kontribusi sector UMKM meningkatkan PDB dari $57,84 \%$ menjadi $60,34 \%$, dari serapan tenaga kerja meningkat dari 96,99\% menjadi 97,22\% (Gunartin, 2017).

Beberapa permasalahn UMKM diantaranya adalah permodalan, kemudian berkembang permasalahan tersebut tentang pemasaran produk-produk yang dihasilkan para pelaku UMKM, kualitas SDM yang rendah dan kurangnya inovasi produk. Permodalan dapat diatasi dengan bantuan pemerintah melalui dana CSR BUMN yang disalurkan dalam bentuk Program Kemitraan dan Bina Lingkungan (PKBL). Kurangnya pengetahuan membuat pelaku UMKM kurang inovatif terhadap produk- produk yang dihasilkan, sehingga perlunya pelatihan dan mencari sumber-sumber pengetahuan melalui internet. Permasalah pemasaran merupakan porsi terbesar dibanding permasalah lainnya (38\% urutan pertama yang disusul $27 \%$ untuk permodalan). Hasil penelitian di Inggris menunjukkan bahwa pemasaran UMKM cenderung terjadi secara spontan, apa adanya dan tidak terarah. Parrot, dkk (2010) mengatakan perencanaan pemasaran UMKM lebih fleksibel dan tidak terlalu memikirkan perencanaan yang berbelit-belit.

Strategi pemasaran pada UMKM tentunya berbeda dengan perusahaan besar, terutama dihadapkan pada anggaran pemasaran yang terbatas. Oleh karena itu, diperlukan kreatifitas bagi para pelaku UMKM untuk menghadapi persaingan yang tinggi seperti pada saat ini. Pada era globalisasi ini para pelaku UMKM dituntut untuk kreatif dan inovatif, agar dapat bersaing dengan lainnya. Sebagian besar UMKM bahkan hasil produksinya belum dapat diterima oleh beberapa mall dan pusat perbelanjaan modern, sehingga strategi pemasaran UMKM perlu diperhatikan oleh semua kalangan, baik pemerintah, masyarakat dan UMKM itu sendiri.

Journal of Dedicators Community $\mid 98$ 
Pada umunya, produk-produk yang dihasilkan pelaku UMKM banyak diminati konsumen, baik dalam negeri maupun luar negeri, hal ini terbukti pada setiap pameran mampu menjual habis produk-produknya. Oleh karena, strategi pemasaran yang hanya dilakukan pada setiap pameran, sehingga sifat pemasaran ini hanya sementara karena terjadi hanya pada momen-momen tertentu dan tidak ada pembelian lanjutan yang dapat mempertahankan bisnis UMKM.

Permasalahan pemasaran umumnya dikarenakan pengusaha UMKM hanya berorientasi pada produk, bukan konsumen; hanya berorientasi pada mencukupi keuangan keluarga, sehingga puntuk memahami strategi pemasaran dengan baik dan sulitnya untuk memberikan merek pada produk-produk yang dihasilkan oleh para pelaku UMKM.

Berdasarkan permasalahan tersebut, pihak akademisi mengajukan untuk melakukan pembimbingan dan pelatihan yang berkaitan dengan strategi perencanaan dan pemasaran yang efektif. Pemberian pengetahuan dan pengenalan tekhnologi kemungkinan dapat memecahkan sebagian permasalahan para pelaku bisnis UMKM.

Permasalahan klasik yang terjadi dalam UMKM adalah kurangnya pengetahuan tentang pemasaran dan strategi yang efektif. Permasalahan ini tentunya berdampak terhadap kemajuan bisnis UMKM itu sendiri, sedangkan bisnis UMKM berkontribusi relatif besar terhadap perekonomian Indonesia.

Oleh karena itu tujuan pelatihan dalam hal ini adalah: 1) memberikan pengetahuan tentang pentingnya strategi pemasaran; 2) Memberikan pelatihan berkaitan dengan pengelolaan dan perencanaan biaya pemasaran yang murah, tetapi efektif; dan 3) memberikan pengetahuan strategi pemasaran yang efektif.

Kontribusi yang bisa diberikan yaitu Para peserta binaan PT Semen Indonesia dapat menerapkan strategi pemasaran yang efektif; membuat perencanaan keuangan untuk biaya pemasaran dengan baik; dan dapat membayar pinjaman dengan lancar.

Pemasaran adalah system keseluruhan dari berbagai kegiatan bisnis atau usaha yang ditujukan untuk merencanakan, menentukan harga barang atau jasa, mempromosikannya, dan mendistribusikannya kepada konsumen, serta bias memuaskan konsumen. Pemasaran sangat penting bagi semua bisnis, tidak memandang bisnis tersebut besar ataupun kecil. Apabila tidak ada pemasaran, maka konsumen tidak akan mengetahui produk atau jasa yang dihasilkan perusahaan tersebut. 
Pemasaran perlu dilakukan dengan baik, sehingga konsumen mengetahui dan tertarik dengan usaha bisnis perusahaan. Dengan demikian, perusahaan dapat membangun kekuatan merk atau disebut dengan brand equity. Brand equity adalah efek diferensiasi positif yang dapat diketahui dari respon konsumen terhadap barang atau jasa (Kotler dan Amstrong, 2004). Berdasarkan brand equity yang baik, nantinya akan menimbulkan brand loyalty, yang berarti kesetiaan pelanggan terhadap produk tersebut.

\section{Ruang Lingkup Pemasaran}

Manajemen Pemasaran terdiri dari kegiatan penganalisaan, perencanaan, pelaksanaan dan pengawasan terhadap program-program untuk membangun, memelihara dan mencari keuntungan melalui sasaran pasar guna mencapai tujuan yang diinginkan. Secara umum lingkup manajemen pemasaran mencakup:

1. Perencanaan Pemasaran adalah pemasaran jangka panjang, perencanaan operasional dan penyusunan anggaran pemasaran barang dan jasa

2. Falsafah Pemasaran adalah mencakup proses pemasaran dan tugas manajemen pemasaran berikut konsepnya
3. Strategi Pemasaran Terpadu mencakup variabel-variabel strategi produk, strategi harga, strategi promosi dan strategi distribusinya

4. Organisasi Pemasaran mencakup tujuan perusahaan, tujuan bidang pemasaran, struktur organisasi pemasaran berikut prosesnya

5. Sistem Informasi mencakup masalah informasi pemasaran, riset pemasaran serta menyusun system informasi pemasaran

6. Kebijakan dan Profesi Pemasaran mencakup masalah strategi orientasi pasar, dan kebijakan menyusun strategi pasar

Konsep pemasaran berbeda dengan penjualan, penjualan lebih menekankan pada produk yang dijual, sedangkan pemasaran lebih ditujuakn untuk keinginan dan kebutuhan konsumen. Perusahaan yang menggunakan konsep pemasaran menganggap bahwa kepuasan konsumen adalah segalanya, sehingga barang atau jasa yang digunakan harus sesuai dengan kebutuhan konsumen. Strategi Pemasaran. Strategi pemasaran $4 \mathrm{P}$ merupakan strategi pemasaran yang terdiri dari empat level keputusan pemasaran, yang meliputi product, price, promotion, dan place. 


\section{METODE}

Metode yang digunakan dalam kegiatan pengabdian ini adalah identifikasi permasalahan dan memberikan pelatihan pemasaran produk kepada UMKM binaan.

1. Identifikasi masalah dilakukan untuk memetakan posisi UMKM dan penyebab sulitnya UMKM tersebut melakukan ekspansi;

2. Pelatihan pemasaran berisi materi tentang marketing mix yaitu:

a. Product (produk) Produk merupakan sesuatu yang dapat memuaskan kebutuhan konsumen, yang dapat berupa suatu barang atau jasa. Yang perlu diperhatikan dalam membuat suatu produk:

- Design produk

- Kualitas produk

- Merek produk

- Kemasan dan label produk

- Layanan yang diberikan, misalnya layanan purna jual

- Garansi

- Pengembalian barang

- Mengelola produk untuk menghadapi siklus produknya

b. Price (harga). Harga merupakan nilai yang konsumen bayar untuk suatu produk.Yang perlu diperhatikan untuk harga suatu produk:
- Strategi dan taktik harga

- Harga diskon untuk distributor

- Harga diskon untuk konsumen

- Pilihan pembayaran

c. Promotion (promosi) Promosi merupakan komunikasi marketing untuk yang dapat berupa iklan dan press release. Yang perlu dipikirkan untuk promosi:

- Proporsi promosi yang dilakukan

- Pesan yang ingin disampaikan

- Media promosi yang dilakukan

- Seberapa sering promosi dilakukan

d. Place (lokasi) Lokasi merupakan bagaimana konsumen dapat mengakses produk kita. Yang perlu diperhatikan untuk lokasi:

- Strategi yang digunakan, misalnya apakah semua pihak dapat menjual atau hanya pihakpihak khusus yang dapat menjual

- Distribusi produk

- Inventori

- Pengiriman dan penyimpanan barang

e. People (sumber daya manusia) Sumber daya manusia adalah orang yang berinteraksi terhadap pelanggan. Hal yang perlu diperhatikan untuk ini adalah:

- Rekrutmen dan pelatihan

- Seragam 
- Cara berkomunikasi dengan pelanggan

- Sistem antrian

- Bagaimana menghadapi komplain

f. Process (proses pengiriman produk) Hal yang perlu diperhatikan dari proses adalah:

- Standarisasi proses

- Memonitor performa layanan yang diberikan

- Analisa dan pengelolaan sumber daya

- Melakukan proses sesuai dengan standar terbaik

g. Physical Evidence (lingkungan) Lingkungan disini merupakan lingkungan dimana layanan diberikan, yang perlu diperhatikan dari lingkungan adalah:

- Fasilitas yang diberikan, misalnya furnitur yang digunakan

- Layout ruangan

- Papan nama

- Desain interior

- Kondisi lingkungan yang meliputi suhu, tingkat kebisingan

\section{HASIL}

Jumlah peserta mitra binaan yang hadir kurang lebih 80 orang, dari berbagai usaha, antara lain usaha garmen, toko bangunan, penjual madu, pembuat seni desain interior rumah, pedagang kopi dan usaha lainnya dibidang peracangan dan toko. Beberapa mitra binaan ini telah diberi pinjaman permodalan dari PT Semen Indonesia, Tbk. Sekitar $75 \%$ mitra binaan ini kesulitan untuk membayar cicilan modal yang diberikan oleh PT Semen Indonesia., Tbk.

Berdasarkan hasil diskusi kelompok, permasalahan yang utama adalah para mitra binaan kesulitan untuk memasarkan produk-produk yang dijualnya. Para peserta tidak bisa mengembangkan usaha, dikarenakan beberapa mitra binaan mengalami ketakutan untuk mengalami kegagalan.

$$
\text { Pelatihan ini memberikan }
$$
pengetahuan tentang pemasaran yang efektif, menyisihkan anggaran biaya pemasaran dan penggunaan yang efektif, dan pengenalan teknologi berbasis web. Para peserta mitra binaan begitu antusias dengan pengetahuan pemasaran berbasis web dan teori-teori lainnya yang sederhana. Permasalahan lainnya, para peserta mitra binaan ini relative kurang kreatif. Tidak ada peserta yang telah menerapkan level keputusan pemasaran, yang meliputi product, price, promotion, dan place. Mungkin hanya place atau lokasi yang

\section{Journal of Dedicators Community |}


strategis, keputusan pemasaran lainnya kurang diperhatikan, terutama promosi.

Biaya promosi dianggap beban bagi para peserta mitra binaan, sehingga usaha para mitra binaan ini kurang berkembang dengan baik. Permasalahan yang ada begitu kompleks, sehingga pelatihan yang dilakukan harus rutin dan bertahap.

Pelatihan ini memberikan teori yang sederhana untuk memasarkan produkproduk yang dihasilkan, agar dapat membantu sedikit permasalahn yang ada saat ini. Permasalahn UMKM tidaklah mudah untuk dipecahkan, mengingat tingkat Pendidikan beberapa mitra binaan yang relative rendah.

Beberapa teori pemasaran diberikan dengan mempertimbangkan tingkat Pendidikan mitra binaan. Para pemateri membawa beberapa contoh produk dan pemaparan yang disertai dengan banyak gambar. Hal ini diharapkan materi dapat dapat diterima dengan lebih baik.

Pemateri pelatihan berusaha memberikan penjelasan sebaik dan sesederhana mungkin, hal ini memberikan respon positif dari para mitra binaan. Hal ini dapat dilihat dari banyaknya pertanyaan yang ditanyakan dan para mitra binaan ini sangat ingin memajukan usahanya. Para mitra binaan tidak pernah menganggarkan secara tersendiri anggaran untuk promosi.
Promosi yang dilakukan hanya dari mulut ke mulut (mouth to mouth).

Pelatihan ini ditutup dengan pemberian sertifikat dan menerima pertanyaan setelah pelatihan selesai. Beberapa peserta mitra binaan menginginkan pelatihan lanjutan terutama pemasaraan melalui website.

\section{SIMPULAN}

Pelaksanaan telah berjalan dengan baik selama kurang lebih 5-6 jam. Peserta binaan pulang dengan membawa konsumsi dan sertifikat. Hasil dari kegiatan ini dapat disimpulkan sebagai berikut:

1. Pelatihan ini dihadiri kurang lebih 80 peserta mitra binaan PT Semen Indonesia dari berbagai jenis usaha.

2. Peserta binaan mitra PT Semen Indonesia merasakan kesulitan untuk melakukan pemasaran produkproduknya dengan baik.

3. Para peserta mengalami kesulitan yang hampir sama, sulit memasarkan produknya dengan tingkat kesulitan yang berbeda-beda, tergantung pada produk yang dihasilkan. Pemateri telah berusaha membantu untuk menjawab semua pertanyaan dengan baik dengan memberikan beberapa contoh yang disesuaikan dengan bidang usaha peserta binaan. 
4. Para peserta sangat senang dan merasa bahwa pelatihan ini dapat bermanfaat dan membantu mengatasi permasalahan yang berkaitan dengan pemasaran.

5. Saran dari peserta binaan menginginkan pelatihan dengan media online yang lebih banyak dijelaskan.

\section{SARAN}

\section{Bagi PT Semen Indonesia}

1. Pihak PT Semen Indonesia sebaiknya secar rutin memberikan pelatihan terutama dalam hal pemasaran dan pengemasan produk yang baik. Oleh karena, kemasan produk merupakan daya tarik utama dalam penjualan produk.

2. Perlu disosialisasikan pemasaran dengan menggunakan online, karena di era digital yang sekarang ini penjualan secara online banyak mendominasi, agar para pelaku UMKM dapat bersaing dengan produk-produk lainnya.

3. Pihak PT Semen Indonesia perlu memberikan sangsi bagi para pelaku UMKM yang tidak membayar hutangnya, terutama pada saat awal akad kredit.

\section{Bagi Mitra Binaan UMKM}

1. Para pelaku mitra binaan diharapkan dapat secara kreatif menjual produknya, baik jenis barang yang dijual maupun pemasarannya, termasuk kemasan barang yang dijual.

2. Para pelaku mitra binaan hendaknya belajar untuk mencatat pemasukan dan pengeluaran dengan baik, sehingga para pelaku mitra binaan dapat mengam bil keputusan dengan baik.

3. Apabila pencatatan dilakukan dengan benar, maka pencatatan harga pokok dapat dilakukan dengan baik dan menentukan harga jual dengan tepat.

4. Pada era digitalisasi ini para pelaku mitra binaan sebaiknya belajar untuk memasarkan dan menjual produknya secara online.

Para peserta mitra binaan sangat berharap seringnya dilakukan pelatihanpelatihan semacam ini. Hal ini dikarenakan membantu para mitra binaan untuk tetap berusaha menjual produk-produknya.

\section{DAFTAR PUSTAKA}

LPPI, K. Bank Indonesia 2015. Profil Bisnis Usaha Mikro, Kecil Dan Menengah (UMKM). LPPI, KAN dan Bank Indonesia Jakarta Indonesia.[In Indonesian].

Gunartin, G. (2017). Penguatan UMKM Sebagai Pilar Membangun Ekonomi Journal of Dedicators Community | 
Bangsa. Eduka: Jurnal Pendidikan, Hukum, Dan Bisnis, 1(5).

Parrott, G., Azam Roomi, M., \& Holliman, D. (2010). An analysis of marketing programmes adopted by regional small and medium-sized enterprises. Journal of Small Business and Enterprise Development, 17(2), 184-203. 